Deconstructing Oral Histories of Family Strategies through

Record Linkage : Comparing Interview, Tax, Welfare, and

Parish Sources from Early Twentieth-century Finland

\title{
Saaritsa, Sakari
}

2019-04-01

Saaritsa, S 2019 , ' Deconstructing Oral Histories of Family Strategies through Record Linkage : Comparing Interview, Tax, Welfare, and Parish Sources from Early

Twentieth-century Finland ' , Journal of Family History , vol. 44 , no. 2 , pp. 159-180 . https://doi.org/10.1177/036319

http://hdl.handle.net/10138/313100

https://doi.org/10.1177/0363199018820487

acceptedVersion

Downloaded from Helda, University of Helsinki institutional repository.

This is an electronic reprint of the original article.

This reprint may differ from the original in pagination and typographic detail.

Please cite the original version. 


\section{Deconstructing oral histories of family strategies through record linkage: Comparing interview, tax, welfare and parish sources from early 20th century Finland}

Sakari Saaritsa, Economic and Social History, University of Helsinki

ABSTRACT: This article demonstrates empirically how triangulation with other sources can alter the interpretation of oral histories of family strategies. While the interests of oral historians have shifted to postpositivist approaches, basic facts about material context and family events still tend to be drawn from the same narratives. Oral histories of two worker households in early $20^{\text {th }}$ century Helsinki are linked with detailed Finnish tax, parish, and poor relief records. The findings point to a number of significant omissions, turn seemingly innocuous factual statements into meaningful strategic representations, and suggest systematic biases in describing livelihoods and sources of income.

\section{Introduction}

This article addresses the persistent methodological tension between "facts" and "meaning" in oral history research through a triangulation exercise on Finnish family histories. The dominant methodological interest in oral history has for long been in issues like the narrative and social construction of historical memory and identity, rather than extracting facts - to the point of at times making the latter notion seem naïve, outdated and uninteresting. ${ }^{1}$ Yet "facts" seem to inevitably enter into research based on oral sources. On one hand, the same interviews are often used as factual sources on context and material life: what happened, where, with whom. ${ }^{2}$ On the other, the idea of significant omissions, silences and errors is wellestablished in methodological thought in the field; indeed, some of the finest classics in oral history are based on the identification of incongruence, and the very opportunity to analyze it has been presented as a key strength of the material. ${ }^{3}$ This, however, ostensibly necessitates a reference to something factual: that what has been omitted or misrepresented.

The relationship between oral and documentary sources - which should not be confused with that between "meaning" and "fact" - has also for long been described as one of creative clash in the field. For instance Trevor Lummis, who advocated triangulation when writing about the authenticity of oral sources 
three decades ago, took care to not to assert the primacy of one over the other, demonstrating at length how documentary sources could both originate from oral sources and be far more unreliable than retrospective interviews. ${ }^{4}$ More recently, Penny Summerfield has shown through numerous examples beyond classics like Portelli and Passerini how an apparent factual discord either between oral and documentary sources, or between different oral sources, or even between interviews with the same individual, has often been key to interpretation. The current consensus is that using such tensions to interpret material - for instance, noting how crucial female agency can at first be hidden in order to conform with a patriarchal cultural norm when discussing the purchase of a family home in 1950s Brazil, but then become revealed as the rapport with the interviewer evolves - does not necessitate judging which source or version of events is ultimately more "true". ${ }^{5}$ While perhaps epistemologically defensible, in concrete cases this may not be wholly convincing; we still do expect to learn more of the Turin worker community than of the other record keepers in the case of Trastulli, for instance. The interpretation would not be possible if we would entertain the possibility that the incongruence with oral sources might just as well have been entirely caused by all the other records being wrong.

Much has been learned about how people shape their narratives in ways helping them to make their personal histories more meaningful, more palatable or more positively charged. This can understandably be the case in politically charged or extreme circumstances, for victims as well as for perpetrators. ${ }^{6}$ However, in mundane fields like family history as well, juxtaposing oral histories with other material may yield analogical insights. Susan Rogers, for instance, has documented a case where a French local community lamented the gradual demise of the stem family system in the clutches of modernization, and justified individual cases of rigorous adherence to its norms with the defense of fragile traditional culture. Census records, in fact, suggest that stem families were becoming more common as the peripheral region got more prosperous through seizing the economic opportunities of modernizing France. ${ }^{7}$ In oral histories of labour, the nostalgia of community as well as the nostalgia of family have for long been subjected to criticisms based on triangulation. ${ }^{8}$ Paul Thompson's original formulation about oral history as an indispensable tool in making family history more complete and equal may thus seem like a somewhat foregone conclusion. ${ }^{9}$ 
This article presents analysis on a typical oral history subject, household strategies for survival, using two oral histories of urban worker families from early $20^{\text {th }}$ century Helsinki, Finland. Unusually, it has been possible to triangulate the material with archival records on relevant dimensions of family life in great detail: family history, household composition, occupations and income generation, recourse to public assistance. The value of oral history in such analysis has traditionally been seen in shedding light on aspects hidden or distorted by the official record: informal economy, community solidarity, and the agency of those subsumed under collective family records and operating in non-monetary economy, especially women and children. ${ }^{10}$ This is certainly true in the case of early $20^{\text {th }}$ century Finland as well. ${ }^{11}$ However, the analysis shows that omission also work to the opposite direction. People may convey seemingly factual representations of livelihoods, welfare and gender roles, which serve the purposes of their stories, but are at odds with other sources and potentially contain risky gaps and biases for the purposes of writing empirical social history.

\section{Sources, contexts and methods}

The primary material for the exercise consists of two oral histories analyzed for what they tell about household survival strategies and sources of income in early $20^{\text {th }}$ century Helsinki; and tax, church and poor relief records used to triangulate the findings. The oral histories are a part of a larger collection with about 80 informants used for a project on informal assistance, including personally collected interviews as well as archives of previous fieldwork exercises. ${ }^{12}$ The particular cases are from the project "Urban Memory" implemented by the departments of Ethnology and Social Science History of the University of Helsinki in 1999. ${ }^{13}$ Though not unique, they have been selected for amenability to triangulation and relevance to the subject. Representativity is neither claimed nor sought. The exercise merely demonstrates, through real examples, to what extent the possibilities for interpreting the material can be limited if oral histories are used as sources of basic facts about family history without triangulation.

A part of the "Urban Memory" project targeted workers' districts north of the city center. The questionnaire used reflected a compromise between the interests of ethnologists and social historians, 
containing questions on the use of urban space over the life course as well as the experiences of the Great Depression of the 1930s. As such, the latter theme was very appropriate for soliciting descriptions of family strategies. In practice, the interviews differed considerably. The questionnaire was not applied in the same manner in each case, and the narration of the interviewees shaped the course of the dialogue. The style and capabilities of the student interviewers varied. The first of the two cases presented below is based on a session where two female subjects were interviewed together by a female student interviewee. For the second one, two male students jointly interviewed a man. Such variation, however, is not uncommon in oral history projects. As certain "background" or "contextual" elements, such as livelihoods and family composition, which are the target of analysis here, are often extracted from oral histories independent of the subject, this is does not constitute a major problem. Equally, loss of tone, body language and situational knowledge involved in using transcripts may not be as detrimental for this subject as for others: the point of the analysis is that nondescript statements seemingly intended to convey facts rather than meaning can in fact be shown to be pregnant with significance when contrasted with other sources. ${ }^{14}$

The interviews are triangulated with church, municipal tax and poor relief records. ${ }^{15}$ The Lutheran state church records (kirkonkirjat) included names, births, marriages and deaths, occupations, and inscriptions on matters like being born out of wedlock and ecclesiastical events. ${ }^{16}$ Income and family economy can be reconstituted with municipal tax records, which provide a control for the church records, which were not updated as frequently. In addition to incomes, the tax records provide household composition (the names of individuals over 15 years of age and the sex and number of children younger than that for tax deduction purposes) as well as occupations on a yearly basis for all members over 15 years of age, often also when nothing was earned or the main activity was studying. ${ }^{17}$

Welfare assistance is gauged through municipal poor relief records. For the 1920s, a complete record on assistance given by the city on alphabetically organized cards was available. ${ }^{18}$ For the 1930 s, minutes of the sections of the poor relief board operating in different parts of the city have enabled linking decisions with the interviewees when their identity and area of residence were known. ${ }^{19}$ Assistance was granted piecemeal in small sums, often earmarked for specific purposes such as firewood or clothes for children, or 
in kind. Everything was still expressed in monetary terms as well, and yearly cash values can be computed. Sources such as the address register maintained by the police in Helsinki since $1907^{20}$ or the histories of certain streets and blocks in published volumes prepared by the Helsinki City Museum have been used to complement and corroborate the analysis. ${ }^{21}$ Price indices have been applied to estimate real earnings. The composition and income of the households of the oral history interviewees have been reconstituted for as many years as possible. The findings are presented as empirical narratives and as graphs. ${ }^{22}$

As has been pointed out in previous literature, also the documentary sources contain errors and distortions. They should therefore not be understood as representing truth as opposed to oral history bias. Instead, they represent different, imperfect and in their own ways biased forms of social knowledge, linked to institutional power and occasionally manipulated by the resisting objects of knowledge. The clergy was occasionally behind in tracking family events in church records, and sometimes intentionally kept in the dark, as the cases below demonstrate. The information in tax records was, since the beginning of the 1920s, based on declaration forms that citizens were obliged to fill out. Control reports were requested from larger employers. Those with irregular employment in smaller establishments or on the margins of the labour market were still in a position to decide what to disclose. The tax board set a fixed estimate for those who neglected declaration or whose reporting they found dubious. The board could also allow discretionary deductions to those suffering from hardship. A small matching exercise comparing reporting to tax authorities with household budgets collected independently and with promise of non-disclosure from the same families in Helsinki in 1928 has suggested that what was declared was, at median, close to the primary earnings of the household heads, but less so if various supplementary earnings were taken into account. ${ }^{23}$ Poor relief officials were perhaps inquisitive, but their reputation was often low among their client communities, probably not conducive to trust and truthfulness. ${ }^{24}$

The interviewees had been born into worker families in Helsinki in the 1910s and the 1920s. Their parents, the main protagonists of their stories, had been born in the 1880 s. The historical context of their family histories was mainly the first half the 20th century, a period of intermittent crises, growth and upheavals in Finnish economic, social and political history. At the eve of World War I, Finland was still autonomous 
Grand Duchy of Russia, with breakaway and independence followed by a bloody Civil War taking place 1917 to 1918 . The 1920s was generally a period of robust economic growth, and the earnings of workers grew especially at the height of the boom from 1926 to 1928 . This was followed by the Great Depression of the 1930s, which began in Finland already at the end of 1928. Towards the end of the 1930s, standard of living and employment conditions improved again. ${ }^{25}$ From 1939 to 1945, Finland took part in World War II, which brought about mobilization, rationing, food shortages and intense Soviet bombings of Helsinki, as well as employment opportunities on the home front particularly for women. ${ }^{26}$ Peace brought rehabilitation and resurgence of the political Left, gradual expansion of welfare services, and after an immediate post-war period of continued rationing and war reparations, acceleration into decades of rapid economic growth.

\section{[FIGURE 1 ABOUT HERE]}

Figure 1 presents real GDP per capita, life expectancy at birth and private consumption over the relevant period in Finland, providing a sense of the macro context. The graphs reinforce the narrative of boom and bust, showing how shocks of war abruptly reversed the gradually declining mortality. They also reveal that the evolution of private consumption was weaker than that of the GDP from the early 1930s onwards, as changes in power relations between labour, capital and the state during the Great Depression and World War II meant that an ever smaller share of growth trickled down to the standard of living of ordinary people. However, in the oral histories, private tragedies such as bereavement or alcoholism often come across as more pertinent than any national trends.

\section{"The Presidentess"}

The Narrative. The first of the oral histories is situated on a crowded municipal tenement block for workers in Helsinki from the 1920s to the 1940s. The narrator herself was born in 1925. Most of the oral history focusses on the life and achievements of her mother. She is presented as a pillar of the community, particularly in terms of community solidarity and assistance towards others. In the interview, she is described as someone who always knew if anyone on the tenement was in trouble. In moments of need, she was there to help by organising collections, and acted as an intermediary towards authorities in charge 
of dispensing assistance and benefits - an informal advocate, to whom people would turn at a time of need.

A1 Our [tenement] had, well, were there a hundred and eighty children all in all.

A2 Ooh.

A1 And of different ages, but all in all. Or was it a hundred and seventy-six. Then there was, here as we had those [tenements], there were over three hundred then and in the plastered houses [a marginally better municipal tenement] had... I can't remember. But mother knew them all, as she...

A2 Yeah.

A1 Took care. As she was that sort of a person, that she took care of everyone's...

A2 And helped families.

A1 helped everyone, and if there was any necessity, she passed around a list. I remember when I was just a little girl, I went from door to door. Someone gave one markka, someone fifty penni. That's the way we managed to get help for the family. ${ }^{27}$

A1 When homes were bombed [during WWII] we were filling out the forms [for assistance], you know. I filled them up, we listed everyone's things and everything there had been, you know, and I remember there was, there was a lot. And you know I, I didn't take any payment for that when I filled out their papers. We were that, we were like the advocate bureau of [the neighbourhood], a free one. And any grievances you had, they always came to talk to us and then [my mother] always went.

A2 To take care of the matter.

A1 To take care. ${ }^{28}$

Informal solidarity is a major theme in the narrative. There are 24 separate concrete descriptions of informal transfers of money, goods and services with the household as a participant. There are five descriptions where something was apparently received, and three describing an exchange of some sort. In the overwhelming majority of the cases, altogether 16 , however, this female-headed, single-parent household appears in the role of the provider of assistance: feeder of beggars and neighbours, advocate for 
others towards the officialdom, supplier of help to the aged and the infirm in the neighbourhood. In the 1930s, solidarity also extended beyond the tenement.

When there was that time of real depression, when people were in want, and you had the unemployed, they went from staircase to staircase, begging behind doors. And we, too, had those young men coming, so my mother always said that you can get food, but she doesn't have any money to give. You can eat. She always cooked that much in excess. ${ }^{29}$

As an advocate for others, she is described as building up social capital to the point of becoming a local informal dignitary - the "presidentess".

And she was, she went by the name of the presidentess ${ }^{30}$ of [the neighbourhood]. [...] And they always said when she went on the street, when she went, when she went out there to take care of those things [...] they said "there goes the presidentess of Vallila again, where did she go now?"31

The activism also had a political dimension, which gained more weight over time and led to significant recognition. The tenements were a site of a left-wing counterculture expressed in local talk and custom, such as using "bourgeoisie" as a pejorative term or knowledgeability of the songs of the labour movement among children. ${ }^{32}$ By her 70th birthday, the standing of the mother was such that top figures of the Communist Party of Finland, again legal after WWII, paid her a visit.

Everybody came. We had a hundred and fifteen people all in all then [...] There was a choir singing behind the door and then, before six, the traffic started. And my [...] son [...] slept in his carriage the whole day [under a window]. I only went by to feed him, but I took him there, as he couldn't have slept at home, as we kept having [people over]... [...] As she was, she was, she was that sort of a person, an organisation person ${ }^{33}$ and she was always busy. ${ }^{34}$

The general secretary of the Party, a parliamentarian and a notable poet of the movement are named among the guests. All in all, the narrative reflects a classic motif in left-wing labour history, where protopolitical everyday community solidarity, an antagonistic counterculture and politics became harmoniously fuse into one. 
Out of the altogether nine mentions of formal welfare from organisations or institutions in the oral history, there are four instances where members of the household are described as having received something: a placement through a labour exchange, employment in public relief work, access to a summer camp for children, cloth from a non-governmental charity foundation after WWII. There is one mention of municipal poor relief, but it is implied that the mother only visited the office in the cause of others. At the same time, there's no mention of any sort of employment on her part. Based on the information give in the oral history alone, the role of the mother as a helper of others would seem somewhat surprising - as, in fact, would the sheer survival of the family.

The Reconstitution. What was the history, composition and economic position of this household from the perspective of other sources? Born in the early 1880s in eastern Finland, the mother migrated to Helsinki in 1902 , listed as an "outworker" in the church records before getting married to a worker 10 years older than herself. The husband's well-specified occupations ${ }^{35}$ and the fact that the couple is at one point briefly noted as owning their home in 1914 give an impression of doing relatively well. ${ }^{36}$ However, things took a decisive turn for the worse as the mother was widowed in 1916 with three children, one of whom passed away later the same year at the age of three. ${ }^{37}$

During the years 1917 and 1918, informal assistance from a relative seemed to be mobilised. A woman in her early twenties with the same last name as the mother's maiden name appeared in the household. Her occupation is stated as "child nurse" in the tax record, while the mother is listed as a "general worker" and a "cleaner". Most probably, the children were cared for by a young female relative, enabling the mother to work elsewhere.

By 1919 , the pattern is disrupted as the relative disappears and the mother moves to a new address, still in the same area, now listed as a "general worker". In 1920 the first record of her whereabouts in the police address register indicates entry to a municipal poor house in November, and that was where she remained in 1921. The next two years she had a new address in the neighbourhood, listed as a "seamstress" in 1923. 
One of the children, a boy born in 1907, is now missing from the records. Interestingly, next to the mother lived a couple with the same last name as someone later identified as her cousin in the oral history - the wife of the janitor of the tenement. This could suggest some sort of a kinship network possibly mobilized to gain access to municipal housing later. In 1924, however, the mother disappears from the records to appear again in 1925 in yet a new address in an adjacent part of the city as a "general worker". This was the year when the interviewee was born.

As the interviewee's childhood experiences began to accumulate, it seems there was a marked stabilisation in the family situation. Already in 1925, the missing son, now 18 years of age, resurfaced into the household, employed and earning. In 1926, the mother moved into municipal housing for the rest of her life. At that point, the household consisted of the mother, children aged 19 and 15, and an infant. Two years after the birth of the interviewee, the mother quit the church for the civil register for a period of time - not a trivial act in a country as dominated by the Lutheran state church as Finland at the time. The timing may have had something to do with the attitudes of the church towards having children or cohabiting out of wedlock, very pertinent in the second case analyzed below. In the light of later events, the life course of the mother shows some early indications of nonconformity in terms of gendered behaviour and family life. All of the children from her first union were actually born before the marriage of the parents, which took place only in 1914. The pattern may have been deliberate. According to the church records, intent to marry was first announced already in 1908. Throughout the interview, the narrator refers to the dead husband as the "first" spouse of her mother. However, there is no trace of a second marriage anywhere in the records. This suggests an informal union, possibly cohabitation, might have taken place with one or more partners later in her life. ${ }^{38}$ Any other partners of the mother are not discussed in the oral history.

As the older children started to come of age, they entered the labour market and generated income. The son moved out around 1929-30, and appeared with a spouse from 1931, starting a family of his own. The next child in line, a daughter born in 1911, was listed as a "pupil" in the tax record in 1929, implying some sort of secondary or vocational education, but entered the job market with the ungratuitous title of 
"general worker" the next year as the Great Depression deepened. Income was indicated in 1930, but for the next time only after the worst years of the depression, in 1934. However, this could very well have been caused by tax exemptions granted on the grounds of low income or difficult family situation.

The older daughter moved out in 1935 , but remained close by on the same tenements and did not marry at first, apparently briefly coresiding with her mother again in 1938-1939. She finally moved elsewhere in 1940 and was recorded as married in 1941 - the very same year the interviewee herself is first indicated to have had an income. Although the mother is listed with an occupation, mostly "general worker", until 1943, there are only a few years where the tax records show she herself was taxed for income, although the previous reservation about the meaning of such blanks applies. The timing of the recorded earnings, however, suggest periods of historically high labour demand supported peripheral workforce: the peak of the boom preceding the Great Depression until its effects started to be felt in earnest in 1928-1930; and the war year 1943, reflecting scarcity of labour on the home front.

The timing of entry to employment and leaving home by the siblings, then, seems to reveal a neat logic where everyone supports the mother in turn as they grow up and enter the labour market, the eldest sibling always passing the baton to the next in line and moving on to start his or her own family. In the early stages, it also seems that municipal welfare, in the form of institutional care and housing, played a very important role in overcoming the crisis initiated by widowhood in 1916. This impression is reinforced by the actual poor relief records.

\section{[FIGURE 2 ABOUT HERE]}

Poor relief sources reveal that the mother was, in fact, a permanent client, receiving assistance in cash and kind with only minor interruptions from at least 1921, when systematic records begin, but most likely already before that, and until 1942. There were well over a hundred decisions made regarding her by municipal welfare authorities during this period. The numerous advances granted beforehand by municipal social workers and accepted in section meetings testify of a much larger number of petitions and encounters. The reasons for assistance recorded were usually one or more of a regular set: sickness, family 
size, supporting the children, unemployment, or specific needs such as medical care, eyeglasses, or rent arrears. Assistance was provided in cash and sometimes in kind, in the latter case often in the form of firewood. This potentially quite significant public assistance goes virtually unmentioned in the oral history.

[...] previously you had the office of the Maintenance board ${ }^{39}$ there in the corner [...] And there many times our, my mother went. You see, there you had Miss [...] and she was of the sort that she kept terrible discipline for those families, and when they were assisted from there, they gave a few tenners of money, if they had any. There was someone who sought divorce from her husband [...] the man was an alcoholic, and of the type that he always beat her. She made her, this Miss [...] "go take back your husband". ${ }^{40}$

In this excerpt - the only one referring to poor relief - it is recognized that the mother frequented the office, but the description immediately turns to the problems of other families. In the context of the oral history, with constant characterizations of the mother as an informal advocate and helper to others on the block, one easily gets the impression that the mother went to the office on their behalf, not for herself.

A reconstitution of the household income package is presented in Figure 2 . The bar chart is intended to describe the composition of income and the timing of changes, not earnings levels or potential standard of living. For the latter purpose, income is deflated with relevant price indices and related to the number of household members in Figure 3.

Preceding the stabilization of 1926, the year 1924 has been intrapolated for household size in Figure 3, as tax records are blank, and only poor relief income is on record. In terms of household composition, there are also some years in the late 1930s where the narrator herself has not been found. It is possible the records are inaccurate; but there are also inscriptions in the tax records referring to the municipal poorhouse, so it cannot be ruled out she was temporarily placed into care outside home during the bleak 1930s. In terms of household income per capita, the annual fluctuations in these years should nevertheless be considered uncertain.

[FIGURE 3 ABOUT HERE] 
the assistance received by the household was unsurprising and much needed. It is also not unusual that oral histories omit formal assistance, which leads to an emphasis of the significance of informal assistance. ${ }^{41}$ The interviewee also had been a child in the period described, and because of that possibly less perceptive about family finances than an adult might have been. ${ }^{42}$ The interview did not systematically probe for a comprehensive view of the family economy, and was ultimately based on what the interviewee remembered and wanted to share. As such, this is still normal raw material for reconstructing the factual background of a family in oral history.

In this particular case, the omissions can arguably be characterized as strikingly misleading. The representation of the mother as a successful social and proto-political activist in the oral history is internally consistent and appealing, and decidedly impressive even with the missing pieces added. As a whole, the case shows that in the context of a rudimentary municipal "welfare state" and Left political culture, a social position that could easily have led to stigma and marginalisation in mainstream social order could still turn out conducive to empowerment. However, a strict reliance on the oral history and the omission of the role of the municipality and the income generated on the labour market by largely unmentioned household members would lead to a serious misrepresentation of the opportunities available for the poor and the material foundations of working class life in Helsinki in the 1920s and the 1930s. In terms of sheer survival and financing the successful political microentrepreneurship of the mother, work for wages and public welfare mattered more than the celebrated informal community solidarity.

\section{"The Useless Father"}

The Narrative. The second oral history centers around the survival struggle of a female-headed household in which the narrator, a male born in the 1910s, grew up with his brother in a densely populated working class neighborhood. A third brother, born in the year of the Civil War, is mentioned to have succumbed to the Spanish Flu. A key figure and the main culprit of the story is the father, an outworker described as an alcoholic, who eventually had to be turned away from the family home. 
And it was miserable in the sense that, well, our mother was not married. There was a father then in the beginning, but we drove him away as he was an alcoholic, so then we had... at night we always had a couple of lodgers to stay there then, because at that time, say around 1920, it was difficult to find lodgings, so they would always sleep over at our place... mom got some extra earnings that way. ${ }^{43}$

[...] He was a Swedish-speaker from [a nearby region]... I guess he was a farm labourer or what was he, but he was good with his hands. He was able and he made all kinds of woodworks, but I was about four when mom drove him away because he was of no use, he just drank. ${ }^{44}$

As the first quotation hints, the mother and the brothers were subsequently driven to an urban economy of makeshifts to make ends meet. In addition to taking in lodgers, the oral history cites strategies such as defaulting on rent and moving house, sending children to beg for potatoes from neighbours on Boxing Day, and finding work running errands and shoe shining.

She [the mother] was from [a province in Eastern Finland] and knew how to read, but she could hardly write and did manual jobs at construction sites and elsewhere. But that was a bit poor as well...The worst of all was in the thir... I was... I did a bit better in the summers when I was shining shoes. In the beginning I was what they called a nurkkari ${ }^{45}$, a wild one; I did not have a license, that is. Whenever the police showed up, I had to run away. But then later on I was... I don't know if you've heard of it, the YMCA organized a kind of a shoe shine crew in the summers. They had a license for it. Benches all around. It was probably these... after the civil war you had a lot of fatherless boys. They tried to help them. So over the summers I made, let's say I was $12-14$, so over the summers I could make up to 1200 markkas per month, that's as much as a hand at the construction sites. ${ }^{46}$

The father only makes a reappearance as an exploitative figure, extracting labour from his children and appropriating the earnings to satiate his endless craving for alcohol.

Interviewer: So later on, did you have any contact with your father?

In the sense that I knew... I mean he was living away and I can tell and I can tell you when I went [...] I was working in the mornings, so I went in the afternoon [...] [to a block nearby] where you had some so-called better folks living, as they say. And it's hard to explain how I ended up sawing firewood there; a job like that. Well my dad went and took the money and drank, until there was nothing left. ${ }^{47}$ 
The years of the Great Depression in the 1930s are described as a period of particularly severe hardship. When formal poor relief is discussed, its humiliating and repulsive nature is emphasized. The narrator emphasizes how no assistance was received, apart from public food distribution and an occasional meal from the Workers' Association.

And I can also tell you as we were having hard times, so I had to go to the poor relief board. As they said at that time. [...] they did humiliate you. They spoke Swedish with each other, and they did not understand that I had been to Swedish day care and school. I was about eight when I went there. I did not want to go much anymore. ${ }^{48}$

[...] The worst was the depression 1930-32, when well I fell through the cracks, I was not yet 16 so we were, my brother was without a job and I was without a job. We had no income at all anymore and I no longer went to get anything from poor relief. We got nothing from nowhere and we went with my brother there [...] behind the tram depot and there was some sort of a barrack on the square. They served oatmeal in the morning and potato soup in the afternoon. For a year I went there, that was all I was getting. ${ }^{49}$

The main theme of the narrative is the independent survival in the family without public assistance or a male provider. The oral history of this experience is ultimately used as a commentary on the presumed rampant welfare dependence in modern Finnish society - a trope not uncommonly encountered in oral history fieldwork on the 1930s.

For example, I worked in this German electrical company [...] It was an errand boy's job. I did try to get to work there even for free if I could get to learn something, but they weren't taking anyone at that time [in the early 1930s]. It was a tough time... What was special at that time was that when you were born out of wedlock, you were a bastard. Even at school they might... teachers might persecute you. When you were raised on poor relief, you wore these gray clothes made of frieze and then you had these shoes, with hairy leather on top and wooden bottoms. They were good in the winter, when you took the heels off you could slide down the tram line on [...] street. [...] It was such a damn hard humiliation, the poor relief system at that time, that I have to say that when I went to study after the war I could have gotten something, but I didn't go apply for anything from anywhere. It was like 
poison for me... I have never understood these people these days for whom everything has to be ready, and the state has to pay. ${ }^{50}$

The excerpt also shows clearly the risk of stigma and humiliation associated with being born out of wedlock and receiving poor relief. This vulnerability is precisely what "The Presidentess" was able to negotiate in the previous case, with the support of a locally rooted counterculture. Contrary to The Presidentess, however, the narrator in this case professes anti-Communist convictions.

What I wonder by the way is that even though I always had a miserable time, I was never Communistminded. I saw already in my time in the military, when I was serving back in the days, that when your superiors told you to do something, those guys went and laid themselves flat in the field, they didn't do anything. That doesn't work, does it. You have to have initiative and would I say dignity, that you know what you are doing and then have vocational pride I have always said, that you do not let bad work out of your hands. They built so damn badly back then [in the postwar years of Left ascendancy, SS] and everyone was just saying that this isn't going to be for me anyway. That's bad spirit. And I don't understand that the socialists came particularly from good families, that they did not have more sense than that. And then when the Soviet Union fell they started to apologize, like that [known journalist], guys like that really make me angry... you'd think that as they were educated folks, you'd think... ${ }^{51}$

Later on in life, he progresses through studies to be the executive director of the Finnish branch of a foreign-owned private company.

The Reconstitution. Triangulation again reveals a number of pertinent omissions. It turns out the mother, born in the 1880s, had been previously married to someone else. The inscriptions in the church records indicate her husband emigrated to America, possibly absconding from the family, in approximately 1908. What is more, the couple had also had a daughter, born a few years earlier. The tax records seem to clearly indicate that she was both living with the family in the 1920 s and working and contributing to the household income during the narrator's childhood years. Exactly how much is not clear, as the income has 
been estimated by authorities due to non-declaration. Her occupation has been listed as "servant" for three of the four years 1923-1926 for which there is an individual record, and "seamstress apprentice" in 1924. Regardless of this, the oral history explicitly delineates the family as consisting of the mother and her three sons with her second partner, one of whom had passed away.

We were originally three sons, mother and father, but mother turned father out as he was an alcoholic. And she did not get married either when she noticed what he was ...three children had been born....the youngest died then....he was born in 1918. My elder brother must have left very early 'cause I can't remember him... I was twelve years old and he had already left. ${ }^{52}$

Neither the half-sister nor the first husband are mentioned or alluded to in any way. It is difficult to determine why. The records indicate that the mother had her first child with her new partner already in mid-1910, suggesting a relatively quick discovery of a new spouse. They also indicate that the first husband had been married for the second time as well, having legally divorced his first wife only 10 months prior to the birth of the half-sister. Possibly, the interviewee is not willing to discuss this in order to not to "discredit" her mother, having himself born the stigma of "bastard" as a child. There is a dramatic and cryptic inscription in the church records supporting this: as late as in 1938, the mother had been "chastised for whoredom" (ripitetty huoruudesta ${ }^{53}$ ), a procedure where mothers with children born out of wedlock were sanctioned in church with varying degrees of publicity and humiliation, made to confess and repent, and eventually readmitted to parish. ${ }^{54}$ It is again hard to tell what had happened. Is it possible that some new information on the extent of cohabitation has transpired to the parish priest at this point, triggering the procedure against the will of the mother? Or is it possible that it was the mother herself who had turned to the church in her late 50s, seeking reintegration? While it cannot be known whether contemporary Lutheran state church hegemony with its discourse on "whores" and "bastard sons" was in this case recognized by its objects as well, this event taking place over 20 years after the birth of her youngest son implies enduring pressure.

On the other hand, the relationship with the half-sister might have been strained in some other way. She apparently married a sailor and moved to England in the beginning of the 1930s, in the midst of a 
deepening economic crisis. This may have been bad news for the rest of the family both economically and socially, signaling weak attachment to the family. However, in these years described as extremely difficult, it is not clear whether she would have been a potential worker or yet another mouth to feed. In any case, the complete omission of an earning female household member certainly distorts the picture of the household economy.

As for the "useless" father, the narrative states that he was turned away for being a drunk when the narrator was about four years old. However, sources reveal significant ambiguity related to the timing of this event. According to the tax records, the household actually only dissolved in 1926-27, rather than around 1920. Over the 1920s until 1926, the family is listed as residing in the same address year after year. In 1927, the father temporarily disappears from the records completely, and a new address is noted for the others. At this time, the narrator would have been approximately ten rather than four years old.

Why does this matter? The oral history insists that drinking was the cause for the banishment of the father from the family home. However, poor relief records mention the father's habit already in the early 1920s, with a marking on the poor relief card from 1923 stating that the father of the children lives with the mother and is "...attracted towards strong drinks". ${ }^{55}$ While the tax records would seem to indicate continued coresidence, the poor relief records also show that the authorities were intent on recollecting from the father some of the assistance they had had to pay to the mother. The 1922 Law on Poor Relief (köyhäinhoitolaki) made this possible when it was deemed that someone legally responsible for supporting someone else had failed to do so. ${ }^{56}$ In this case, paternity was the basis for the obligation, and working and earning was an indication of the capability to provide support. The need to recollect is noted in 1924, and with particular insistence for several payments made in 1926. This would certainly suggest less than harmonious household relations. From 1927 onwards, intent to recollect is no longer mentioned.

[FIGURE 4 ABOUT HERE]

In terms of the explanation of the dissolution of the household, there are some important particularities related to the inscriptions for the year 1925. It seems that at this time, the mother had succeeded in 
convincing the tax authorities that the couple was, in fact, married. The text "husband and wife" has been handwritten on the page of the tax record. Church records show this was not the case at parish. Civil marriage was legally possible since 1917, but rare and unlikely. This is important for two reasons. Firstly, if the father would definitively have been excluded from the household already years earlier, it would have been surprising that the couple would have been presented as being, or believed to be, married. Secondly, marriage would have had major implications for the taxation of the father (as well as the reconstitution of his earnings). For a married couple with underage children, a so-called "child deduction", slashing 1200 mk per child under 15 years of age from taxed income, was routinely granted to the father. This meant a smaller tax burden (and also needs to be taken into account in the algorithm estimating annual earnings). If the mother would have been considered the sole caregiver of the family, she would have enjoyed the deduction instead. The records suggest that the claim of marriage was indeed based on the tax declaration she had filed, as the "marriage" has been noted on her line. This move would only have made economic sense for her if the couple was still together in 1925, and the mother was confident earnings would be pooled for the common good of the family.

The sources would therefore indicate a more complex, on-off, and gradually deteriorating situation in family relations than the story of the drunk father abruptly turned out around 1920 . What else might have happened? There are some economic and demographic aspects that provide more context. Firstly, the dissolution of the union seems to have been preceded by a gradual decline in the earnings of the father. The reconstitution is presented in Figure 4. The estimated annual earnings contain a lot of gaps, as discretionary deductions had apparently been granted. In this case, it is informative to observe the evolution of the post-deduction taxed income as well (Figure 5). This would seem to have steadily increased in absolute terms from 1921 until 1924, after which decline set in. For the reasons mentioned in the previous paragraph, however, the outright collapse in 1925 is quite possibly false. If one assumes that this was a year when the father was exceptionally granted child deductions on the basis of a fake "marriage", the estimated annual earnings in nominal terms were around the level of 1922. Strong inflation would have 
led to a deterioration of the real value of income (see Figure 6). By 1926, no taxed income was noted for the father any longer.

\section{[FIGURE 5 ABOUT HERE]}

A demographic observation may also be added. The narrator's father and mother had an age difference of 25 years. He had, in fact, also had three children in an earlier marriage in the early 1890 s, which had ended in the death of his spouse before 1900 . The children had subsequently migrated one by one to another city in Southern Finland in the 1910s as adults. By the time the income stream of this "outworker" in Helsinki in the 1920s known to be "attracted towards strong drinks" dwindled, he was already nearly 70 years old. One could reasonably expect a degree of career slowdown in such circumstances.

Altogether, it may be possible to also take rather literally the statement that the father was sent off at the point of being "of no use" any longer. It seems that cohabitation continued despite of difficulties and alcoholism over the 1920s, and the union was shored up and even presented as marriage to the authorities long after the purported "turning out" of the father according to the oral history. Only at a time when he became incapable of generating an income, either due to advanced age, advanced alcoholism, or both, was the partnership dissolved. The father ultimately died in a municipal poorhouse some 12 years later.

Finally, there was poor relief - as the figures indicate, in reality a constant source of support for the family. Apart from the years 1935 and 1936, assistance was received by one or more of the household members every single year from 1921 to 1942 , the last year on record. While the uncertainty of the tax based estimates make precise calculations risky, its share of household income was likely often large, for instance over the years of the Great Depression. In the years 1930 to 1932, when according to the narrator "we got nothing from nowhere", the mother had received 3800-4100 mk per year, and in 1932 the narrator's older brother, with whom going to public food distribution is described, was the target of assistance worth 1710 mk. In 1928, before the crisis, the median income of a relatively well off male worker in Helsinki based on household budget surveys and tax statistics was approximately $2200 \mathrm{mk}$ per month. ${ }^{57}$ The assistance was typically disbursed monthly a few hundred mks at a time, and was very little to try and survive on. Still, it 
was significantly more than "nothing". Over these three years alone, altogether 9 decisions had been taken on applications from the mother (8 positive) and over 1932 altogether 5 decisions (all positive) for the elder brother.

\section{[FIGURE 6 ABOUT HERE]}

All in all, the oral history narrative in this case originally presents a very clear plot, which is then made ambivalent by the reconstitution exercise. Intentional or not, the narration seems to consistently protect the mother from sources of social stigma while attaching strictly negative significances to the father and to public authorities. This leads to a series of at the same time distorting and meaningful omissions. It seems that the fate of the union with the father of the narrator might have been more starkly dictated by material needs and conditions than the original story suggests, while at the same time decision making related to it by the mother was less clear cut, as testified by the "fake marriage" of 1925 . In terms of livelihoods, what is again left out are types of labour income vital for the family, as well as constant public assistance. This would emphasize the role of an urban informal "economy of makeshifts" in supporting the family, and again downplay the role of the notorious poor relief system. Furthermore, to preserve the integrity of the representation of the family, an entire person, the older half-sister from the previous marriage, has been completely cut out of the picture.

\section{Discussion and conclusions}

While space permits the dissection of only two case studies, they are by no means the only ones providing similar observations in the collection. Others include, for instance, a family losing its sole breadwinner in 1934 that is claimed to have survived strictly on assistance from relatives, but in fact immediately got poor relief, which together with declining prices actually in real terms halted the fall in family income of the previous years; and a family insisting that the Great Depression did not affect their livelihoods in any way due to their father's hard work and enterprise - appropriately contrasted with the lazy modern generations - but actually suffered from a serious earnings decline over a period of five years. What all these cases indicate is the dramatic impact that reconstitution of material life from other sources can have on the 
interpretation of oral histories of family strategies, as opposed to taking them, at least in part, as harmless recital of events while trying to discover meaning from discourse alone.

The importance of triangulation is not primarily a matter of possible factual errors or omissions. The process of reconstitution allows for a more advanced interpretation of the significance of what is being said and the social and cultural context that makes it intelligible in the first place. The cases show that there are patterns in what is being omitted and what is being emphasized, and that these make historical sense. For instance, micro level counterculture in the childhood habitat of the narrator made it possible to discuss nonconformist family patterns with ease in the case of "The Presidentess", who had managed to rise to prominence as a local rebel. However, the centrality of independent agency and community solidarity for the narrative led to a de-emphasis of other elements of survival: income from working members of the household, who are hardly mentioned; and various forms of support from the municipality, from housing via institutional care to almost incessant cash transfers. As individual functionaries of local government are, albeit quite convincingly, presented as insensitive villains with whom the family battles on behalf of the community, their role as providers of sustained support is eclipsed by their casting in the narrative.

On the other hand, the more repressive and stigmatizing climate experienced by the narrator and her mother in the case of "The Useless Father" may still have had have had an effect on what could be told in an interview in the late $1990 \mathrm{~s} .{ }^{58}$ Some people are entirely removed from the picture, and others are assigned roles which serve to protect the integrity of the story and its protagonist, but cannot be considered entirely accurate from the perspective of other sources. Possibly echoing the socially conservative environment surrounding the childhood family, aspects of the story that could in any way be construed as implying promiscuity, shiftiness or opportunistic behavior on the part of the interviewee's mother are cut out - including a daughter from a previous marriage and her contribution to the family economy. The cause for the dissolution of the household is squarely assigned to the alcoholism of the father, who takes on strictly negative roles. The high age difference, the apparent on-off -nature of the relationship, and the coincidence of eventual "throwing out" with the decline in earnings of the elderly father-all important from the perspective of understanding family economies - are eclipsed. 
The exercise also raises general concerns related to the use of oral sources for constructing social history.

One of these is the de-emphasis of income generated on the labour market by various household members, and an overemphasis of the role of informal economy and community solidarity for survival. ${ }^{59}$ Another important bias concerns the poor relief system. In these and other similar oral histories, recourse to municipal assistance is routinely denied. At the same time, the system itself is depicted as humiliating and repulsive. The latter is in many ways understandable. There was local variation, and also more neutral memories have been discovered, but overwhelmingly the board hearings and threats of later recovery of payments from the beneficiaries or their relatives have left a resentful collective memory. ${ }^{60}$ This was also the spirit of the law, which tried to ensure that turning to the municipality would be the absolute last resort. However, during individual and general crises, the poor relief authorities did preside over the disbursement of vital and significant material help to great numbers of struggling worker families, who also readily sought and resorted to the assistance. Reluctance to admit this was probably not only related to negative feelings and experiences over the system, but also to an ethos of independent survival, which somehow did not pertain to informal assistance from relatives or community in the same way. ${ }^{61}$

All in all, the exercise presented suggests that while oral history is in many ways an invaluable source for family history, not only facts but also the interpretation of meanings will potentially be muted in the absence of triangulation with other sources. Omissions are significant, as what is omitted can speak of dimensions like values, stigma and strategies of representation. By definition, omissions cannot be directly read or fully interpreted from a single source.

\section{Acknowledgements}

Funding from the Academy of Finland is acknowledged. The author would like to thank the participants of the seminar Pouvoirs et dépendances au sein de la famille : perspectives comparatives (16e-21e siècles) organized by Antoinette Fauve-Chamoux, Centre Maurice Halbwachs, Ecole Normale Supérieure, Paris, France, March $3^{\text {rd }}, 2016$, the participants of the research seminar in economic and social history at the University of Helsinki, April $18^{\text {th }}, 2018$, the participants of session 37, Perspectives on Family Histories, at the XX International Oral History Association Conference, Jyväskylä, Finland, June 18-21, 2018, in particular Alistair Thomson, and two anonymous referees for encouraging and extremely useful comments. Sinikka Selin provided crucial and skillful research assistance with the collection of the original archival source material in 2005-2006. 


\section{Figures}

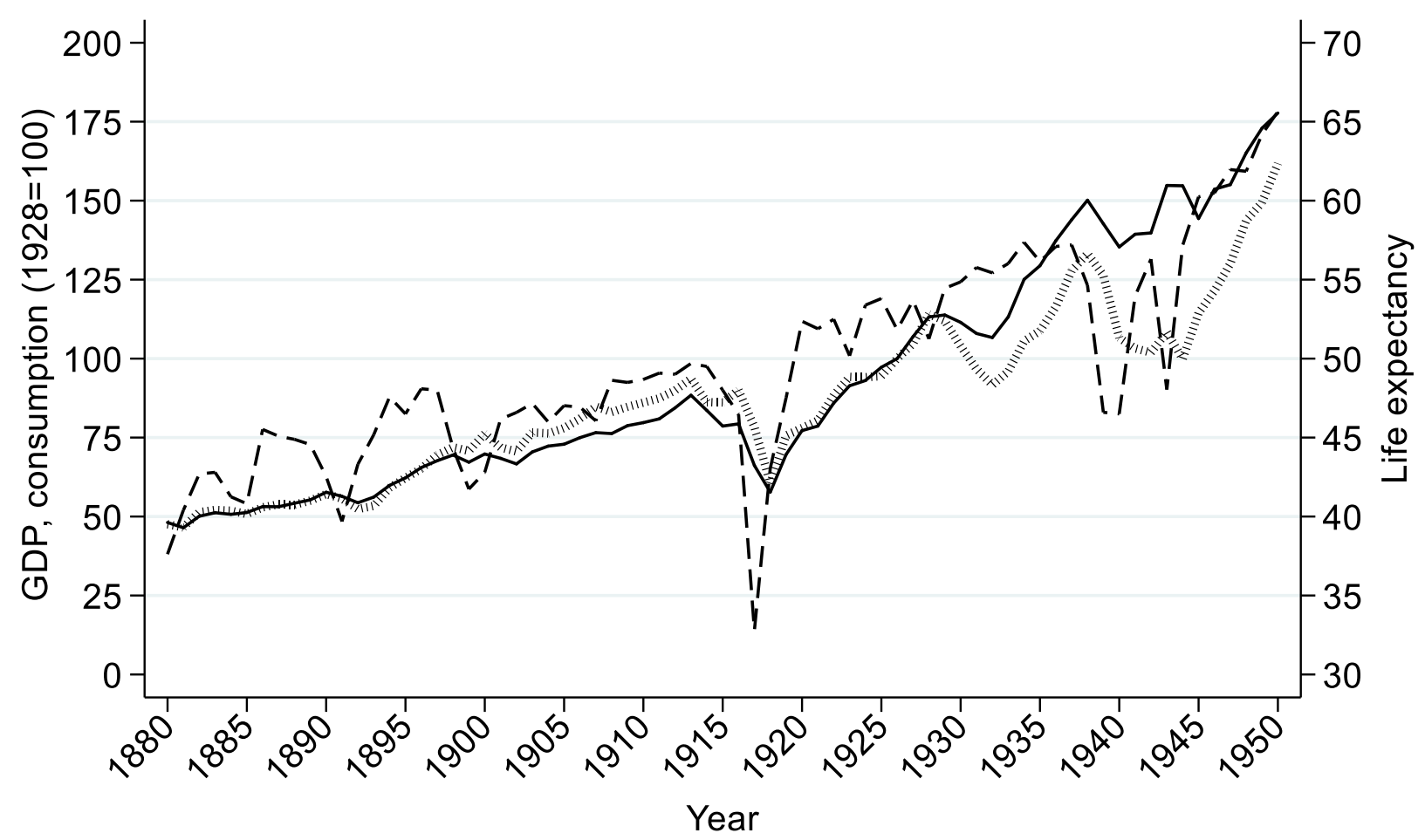

GDP per capita, index

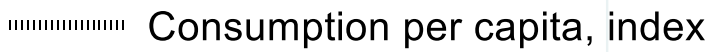

- - - Life expectancy at birth (right axis)

Figure 1. Selected indicators for economic and social conditions in Finland, 1880-1950. Sources: GDP and private consumption: Maddison 2013 / Hjerppe 1988 / Statistics Finland (http://www.stat.fi/til/vtp/tau.html); Life expectancy: Kannisto \& Nieminen 1996. 


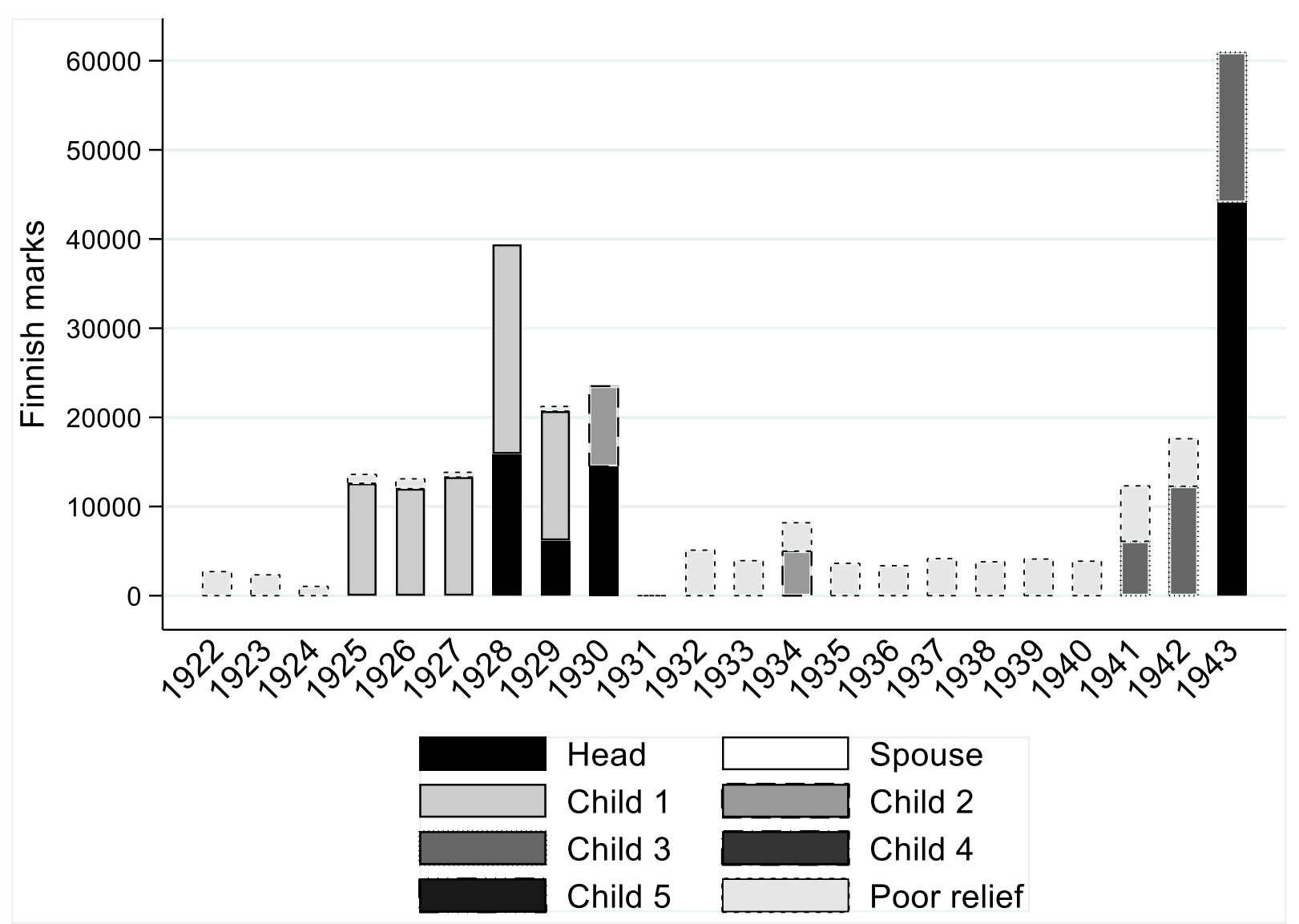

Figure 2. Sources and structure of household income, "The Presidentess". Sources: see text. 


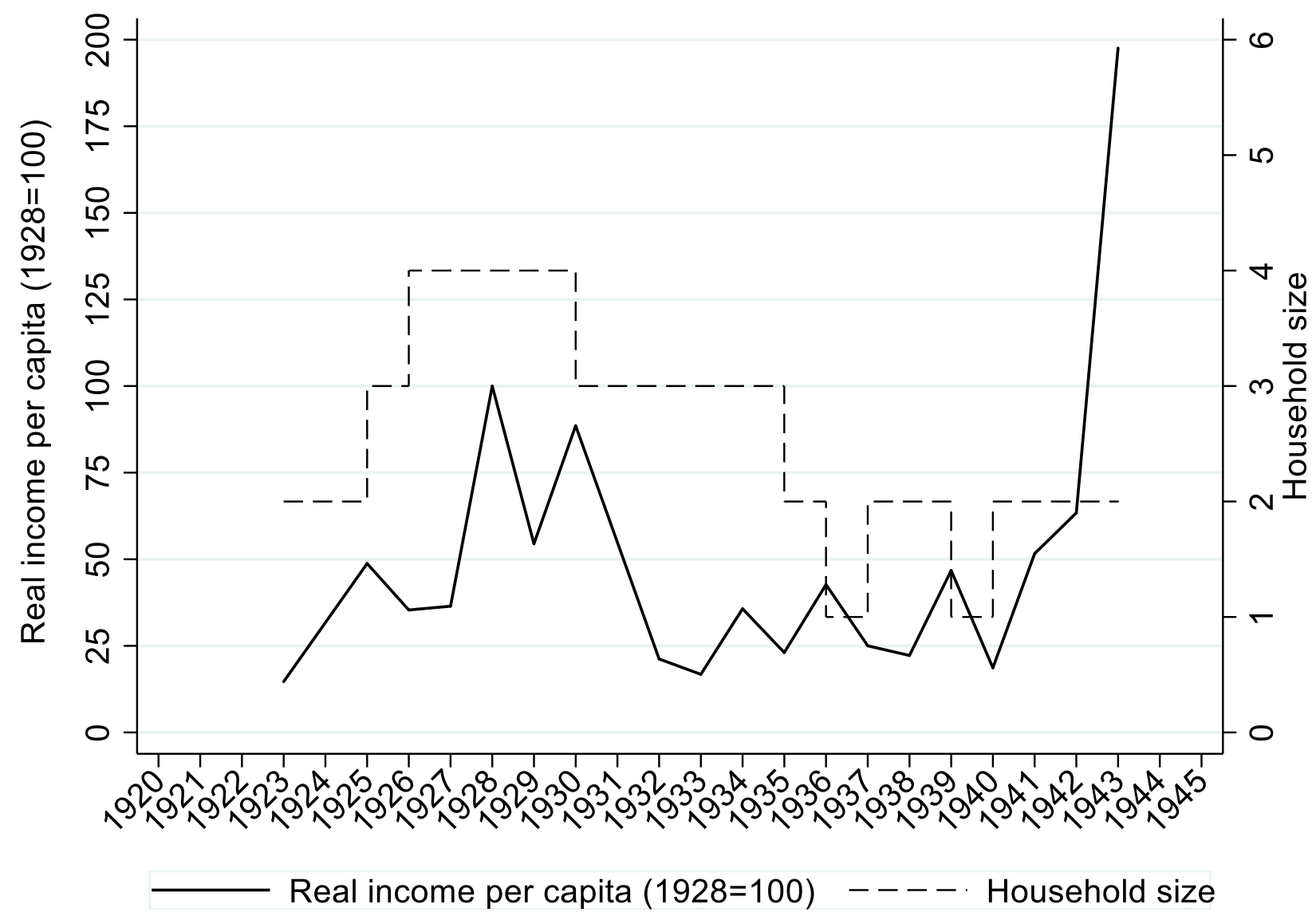

Figure 3. Household size and real income per capita, "The Presidentess". Nominal earnings deflated with cost-ofliving indices based on the Helsinki price index database of Matti Hannikainen. Sources: see text. 


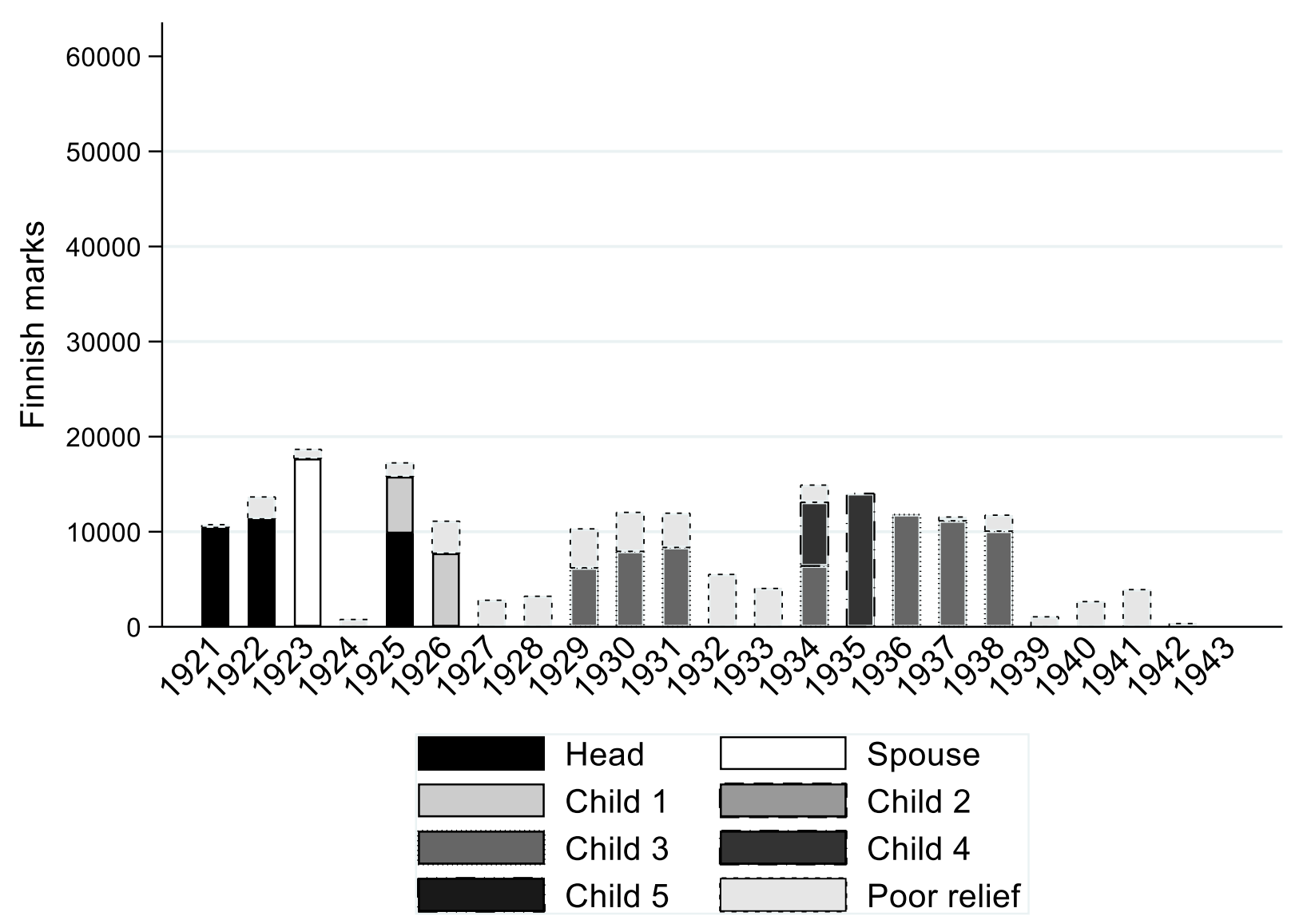

Figure 4. Sources and structure of household income, "The Useless Father". Sources: see text. 


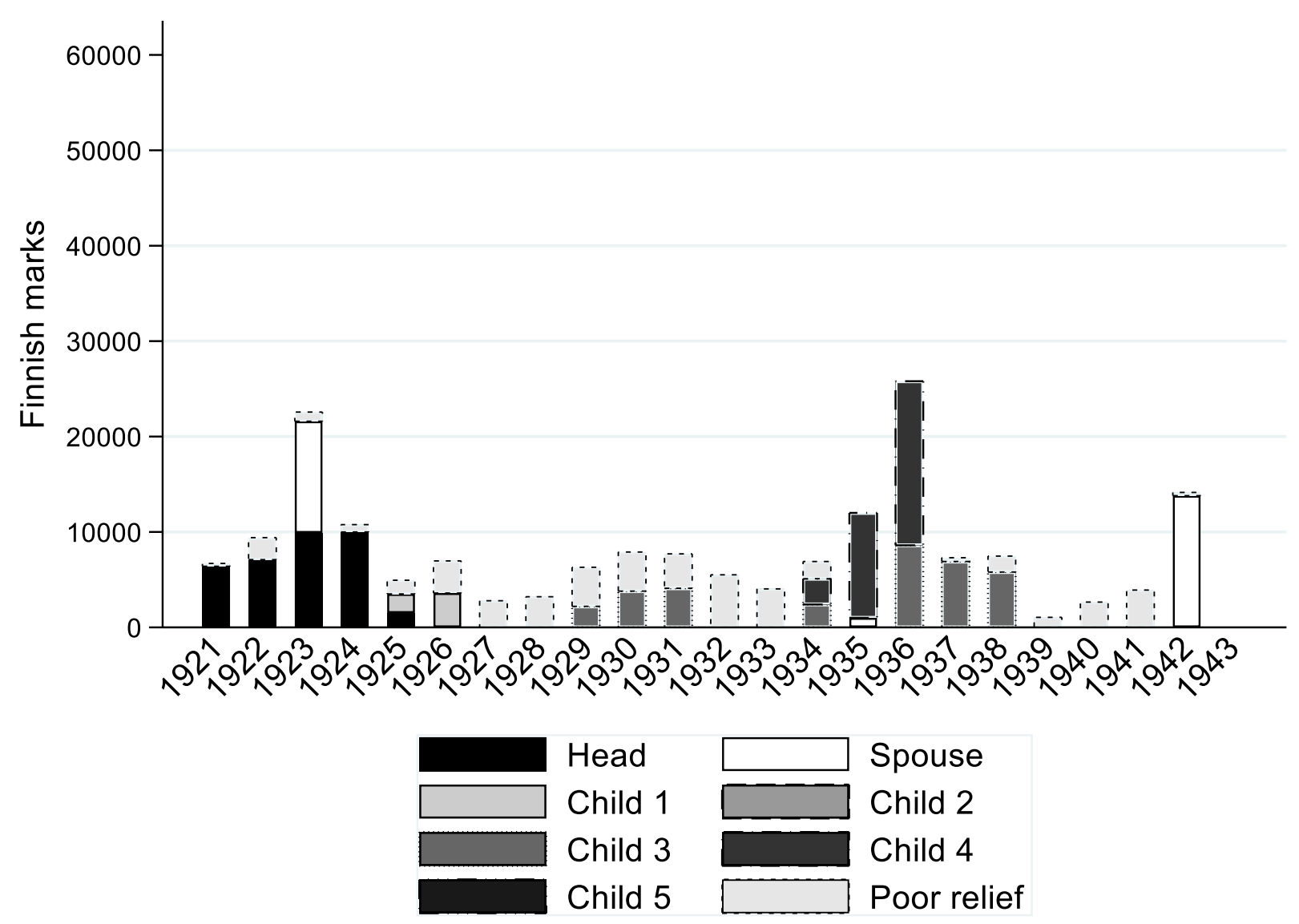

Figure 5. Sources and structure of household taxed income after deductions, "The Useless Father". Sources: see text. 


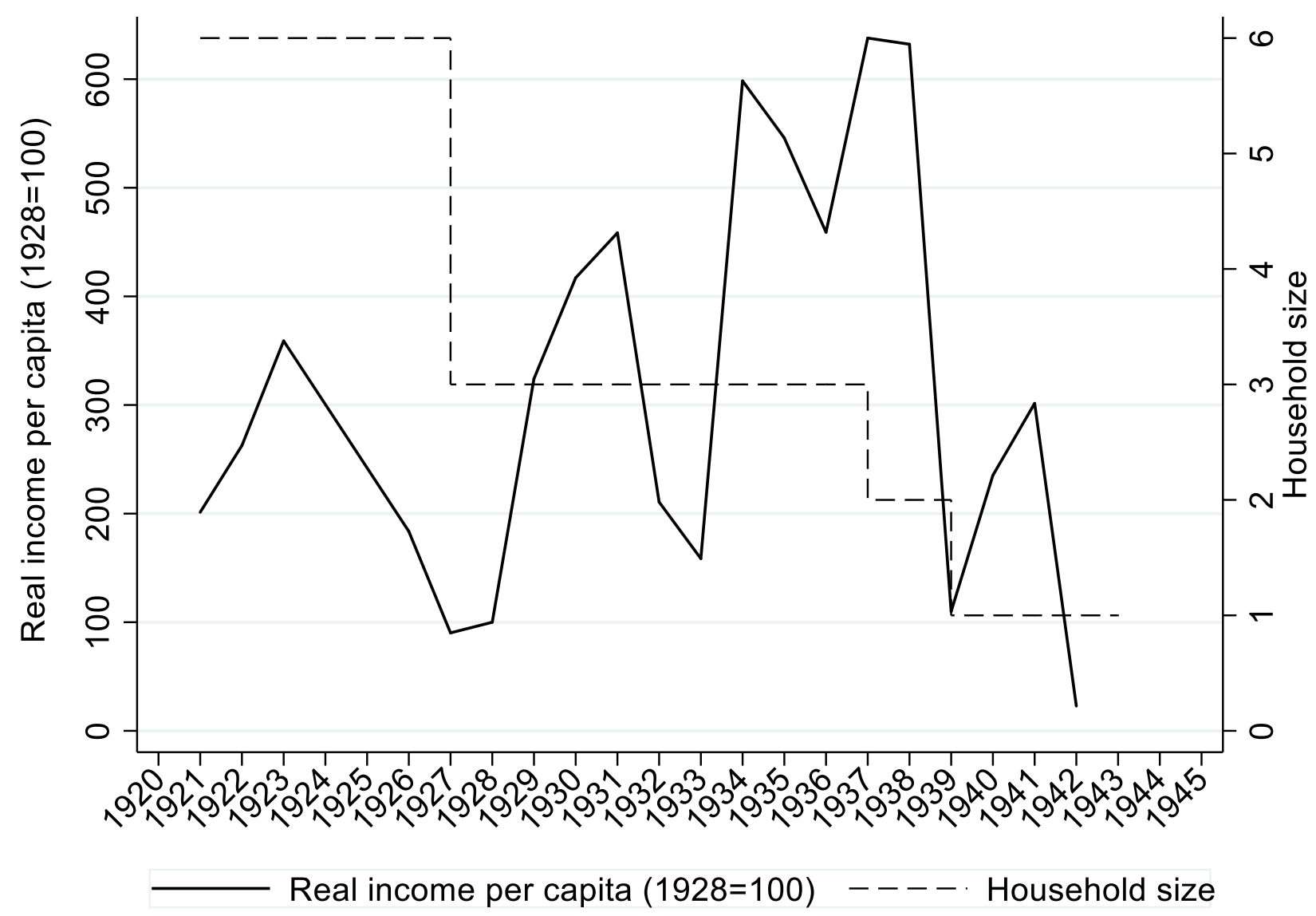

Figure 6. Household size and real income per capita, "The Useless Father". Nominal earnings deflated with cost-of-living indices based on the Helsinki price index database of Matti Hannikainen. Sources: see text. 


\section{References}

${ }^{1}$ Cf. Alistair Thomson, "Four Paradigm Transformations in Oral History", The Oral History Review 34, no. 1 (2007): 4970.

${ }^{2}$ For instance, Penny Summerfield opens her new elaborate methodological book on personal narratives and historical practice with a lengthy passage containing the individual and household history of a British-Jamaican family, describing matters like employment patterns, livelihoods and residence apparently strictly based on the interview itself. Penny Summerfield, Histories of the Self: Personal Narratives and Historical Practice (London and New York: Routledge 2018).

${ }^{3}$ Alessandro Portelli, The Death of Luigi Trastulli and Other Stories: Form and Meaning in Oral History (Albany, NY: SUNY Press 1991); Luisa Passerini, Fascism in Popular Memory: The Cultural Experience of the Turin Working Class (Cambridge: Cambridge University Press 1987); Cf. Ulla Savolainen, "Tellability, frame and silence: The emergence of internment memory", Narrative Inquiry 27:1 (2017): 24-46; Anne Heimo, "The Italian Hall Tragedy, 1913: A Hundred Years of Remediated Memories", In Tea Sindbæk Andersen and Barbara Törnquist-Plewa (eds.), The Twentieth Century in European Memory: Transcultural Mediation and Reception (Leiden: Brill 2017), 240-267; Anne Heimo, "Kapina Sammatissa : vuoden 1918 paikalliset tulkinnat osana historian yhteiskunnallisen rakentamisen prosessia" ["The rebellion in Sammatti: The local interpretations of 1918 as part of the process of the social construction of history"] (Helsinki: SKS 2010).

${ }^{4}$ A case in point were UK government fishing statistics, which his fisherman informants readily disclosed were based on fabricated and purposefully misleading testimony. Trevor Lummis, Listening to History: The authenticity of oral evidence (London: Hutchinson 1987), Ch 1, Ch 7.

${ }^{5}$ Summerfield, Histories of the Self, 106-133.

${ }^{6}$ Kathleen Blee, "Evidence, Empathy, and Ethics: Lessons from Oral Histories of the Klan", The Journal of American History 82, no. 2 (1993): 596-606; Mark Roseman, "Surviving Memory: Truth and Accuracy in Holocaust Testimony", in The Oral History Reader, ed. Robert Perks and Alistair Thomson (New York, NY: Routledge 2016), 320-333.

${ }^{7}$ Susan Rogers, "When the shoe fits: Census data, oral history, and stem families in Southwest France", Historical Methods 25, no. 1 (1992): 20-27.

${ }^{8}$ E.g., Joanna Bourke, Working-Class Cultures in Britain 1890-1960: Gender, class and ethnicity (London: Routledge 1994); Angelique Janssens, Family and social change: The household as a process in an industrializing community (Cambridge: Cambridge University Press 1993).

${ }^{9}$ Thompson, Oral History, 168-173.

${ }^{10}$ E.g., Susan Porter Benson, Household accounts: Working-class family economies in the interwar United States (Ithaca \& London: Cornell University Press 2007); Elizabeth Roberts, A Woman's Place: An Oral History of WorkingClass Women 1890-1940 (London: Basil Blackwell 1984); Ellen Ross, "Survival networks: Women's neighbourhood sharing in London before World War I", History Workshop Journal 15 (1983): 4-28; Tamara K. Hareven, Family time \& industrial time: The relationship between the family and work in a New England industrial community (Cambridge: Cambridge University Press 1982).

${ }^{11}$ E.g., Gia Virkkunen, "Köyhyydestä ei puhuttu, sitä vaan elettiin": Köyhyyden kokemus ja selviytyminen 1930-luvun pulan oloissa Suomen maaseudulla ["You did not speak of poverty, you just lived it": The experience of poverty and survival under the conditions of the Great Depression of the 1930s in the Finnish countryside] (Helsinki: Suomalaisen KIrjallisuuden Seura 2010); Sakari Saaritsa, "Riskeiltä suojaavat verkostot: Epävirallinen apu maaseudun teollisuusyhteisön muistitiedossa kriisiaikoina 1900-1950" [Risk-sharing networks: Informal aid in the oral histories of a rural-industrial community during crisis periods, 1900-1950], In Helena Blomberg-Kroll, Matti Hannikainen \& Pauli Kettunen (eds.): Lamakirja: Näkökulmia 1990-luvun talouskriisiin ja sen historiallisiin konteksteihin (Turku: Kirja-Aurora 2002), 195-232..

${ }^{12}$ Sakari Saaritsa, Beneath Moral Economy: Informal Assistance in Early 20th Century Finland (Florence, Italy: European University Institute 2008 [2008a]), 59-.

${ }^{13}$ For previous published work on the material, see Pia Olsson, "Modes of Living and Local Identity: Formations in two Districts of Helsinki", in Anna-Maria Åström, Pirjo Korkiakangas and Pia Olsson (eds.), Memories of My Town: The Identities of Town Dwellers and Their Places in Three Finnish Towns (Helsinki: Finnish Literature Society 2004), 84-102. ${ }^{14}$ A shared element in all the interviews, potentially creating a horizon of expectation about the genre sought, is a recorded permission to save the material to the collections of Suomalaisen KIrjallisuuden Seura [Finnish Literature Society], a national institution founded in the early 19th century and preserving oral and written cultural heritage. (On 
the effect of target institutions on the style of narration in Finland, see Ulla-Maija Peltonen, Punakapinan muistot: Tutkimus työväen muistelukerronnan muotoutumisesta vuoden 1918 jälkeen [Memoirs of the Red Rebellion: A Study of the Formation of Labour Folklore After 1918] (Helsinki: SKS 1996). The interviews were still decidedly not solemn or conformist in their tone.

${ }^{15}$ This material has originally been collected in 2001-2006 for a PhD project.

${ }^{16}$ Helsingin seurakuntien keskusrekisteri: Kirkonkirjat 1880-1951. [The Parish Union of Helsink: Parish registers 18561950]

${ }^{17}$ Helsingin kaupungin tietokeskus, Helsingin kaupunginarkisto: verovirasto, kunnallisveroluettelot 1907-1943. [[City of Helsinki Urban Facts, City Archives: The tax bureau (Taxation Board + Inspection Board), Municipal tax records 1907-1943] These only provide äyri tax units, but an algorithm exists for converting these back to estimated annual income by adding back rule based deductions, which depended on taxes paid in the previous year, the number of children under 15 and the original income level (Matti Hannikainen, Timpurin töissä ja varatöiden varassa:

Helsinkiläisten kirvesmiesten palkat, vuosiansiot ja työttömyys 1928-1936 [As a carpenter and on relief work: The wages, annual earnings and unemployment of the carpenters of Helsinki, 1928-1936. Master's thesis.] (Helsinki: Helsingin yliopisto 1997); Saaritsa, Beneath Moral, Appendix 1.

${ }^{18}$ Helsingin kaupungin tietokeskus, Helsingin kaupunginarkisto: Huoltoviraston arkisto, Bb:1-78 Huollettavien avustuskortisto. [City of Helsinki Urban Facts, City Archives: The archives of the assistance bureau, Bb:1-78 File cards on the assisted]

${ }^{19}$ Helsingin kaupungin tietokeskus, Helsingin kaupunginarkisto: Huoltoviraston arkisto, CaV:1-CaXV:2 1.-11 Huoltojaoston pöytäkirjoja sotien väliseltä ajalta. [City of Helsinki Urban Facts, City Archives: The archives of the assistance bureau, CaV:1-CaXV:2 1.-11 Minutes of meeting of the assistance sections from the interwar period] ${ }^{20}$ Helsingin kaupungin tietokeskus, Helsingin kaupunginarkisto: Helsingin poliisilaitos, helsinkiläisten osoiterekisterikortit 1907-1974. [City of Helsinki Urban Facts, City Archives: The police department of Helsinki, The address register cards of the inhabitants of Helsinki 1907-1974]

${ }^{21}$ Kaija Hackzell and Kirsti Toppari, Oihonnankadulta Kumpulantielle: Helsingin vanhoja kortteleita 4. [From Oihonnankatu to Kumpulantie: Old blocks of Helsinki 4.] (Helsinki: Sanoma Osakeyhtiö 1991).

${ }^{22}$ For similar analyses in economic and social history literature, see Sara Horrell \& Deborah Oxley, "Work and Prudence: Household Responses to Income Variation in Nineteenth Century Britain", European Review of Economic History 4:1 (2000): 27-58; Maurizio Gribaudi, "Percorsi individuali ed evoluzione storica: Quattro percorsi operai attraverso la Francia dell'Ottocento", Quaderni Storici 106 / a. CCCVI, n. 1 (aprile 2001): 115-150.

${ }^{23}$ Saaritsa, Beneath Moral, 230-250.

${ }^{24}$ Saaritsa, Beneath Moral, 169-170.

${ }^{25}$ E.g., Pertti Haapala, Kun yhteiskunta hajosi: Suomi 1914-1920 [When society fell apart: Finland 1914-1920] (Helsinki: Edita 1995); Matti Hannikainen, Rakentajat suhdanteissa: Palkat, työttömyys ja työmarkkinakäytännöt Helsingin rakennustoiminnassa 1930-luvun laman aikana [Construction Workers and Business Cycles. Wages, Unemployment and Labour Market Practices in the Construction Industry in Helsinki during the Great Depression of the 1930s] (Jyväskylä: Suomen tiedeseura 2004); Klaus Waris, Kuluttajain tulot, kulutus ja säästäminen suhdannekehityksen valossa Suomessa vuosina 1926-1938 [The income, consumption and savings of consumers related to the economic cycle in Finland 1926-1938] (Helsinki: Kansantaloudellinen yhdistys 1945).

${ }^{26}$ E.g., Kari Nars, Suomen sodanaikainen talous ja talouspolitiikka. [The wartime economy and economic policy of Finland.] (Helsinki: Suomen Pankin taloustieteellinen tutkimuslaitos 1966), 42-175.

${ }^{27}$ Q91:4 INTERVIEWEE 1. (The reference identifies the primary document and the quotation in an ATLAS.ti software hermeneutic unit, enabling exact retrieval.)

${ }^{28}$ Q91:57 INTERVIEWEE 1.

${ }^{29}$ Q91:39 INTERVIEWEE 1.

${ }^{30}$ presidentska.

${ }^{31}$ Q91:47 INTERVIEWEE 1.

${ }^{32}$ Saaritsa, Beneath Moral, 163-164.

${ }^{33}$ The Finnish expression used here, järjestöihminen, literally means "organisation person". The word järjestö in the Finnish expression järjestöihminen used refers to political organization, in this case in particular to labour and trade union organisations.

${ }^{34}$ Q91:54 INTERVIEWEE 1.

${ }^{35}$ The husband is listed as a "cement worker" in the church records in 1909-16, but as an "outworker" in the municipal tax records in 1913-1916. In 1906 he makes an appearance as a "stone worker" in the tax records, a category in some cases referring to skilled labour, although "cement worker" would most likely have been less skilled. In any case, the mention of an occupation is a hint of a more steady position than placement in the category of a sekatyömies / sekatyöläinen, i.e., "general worker". 


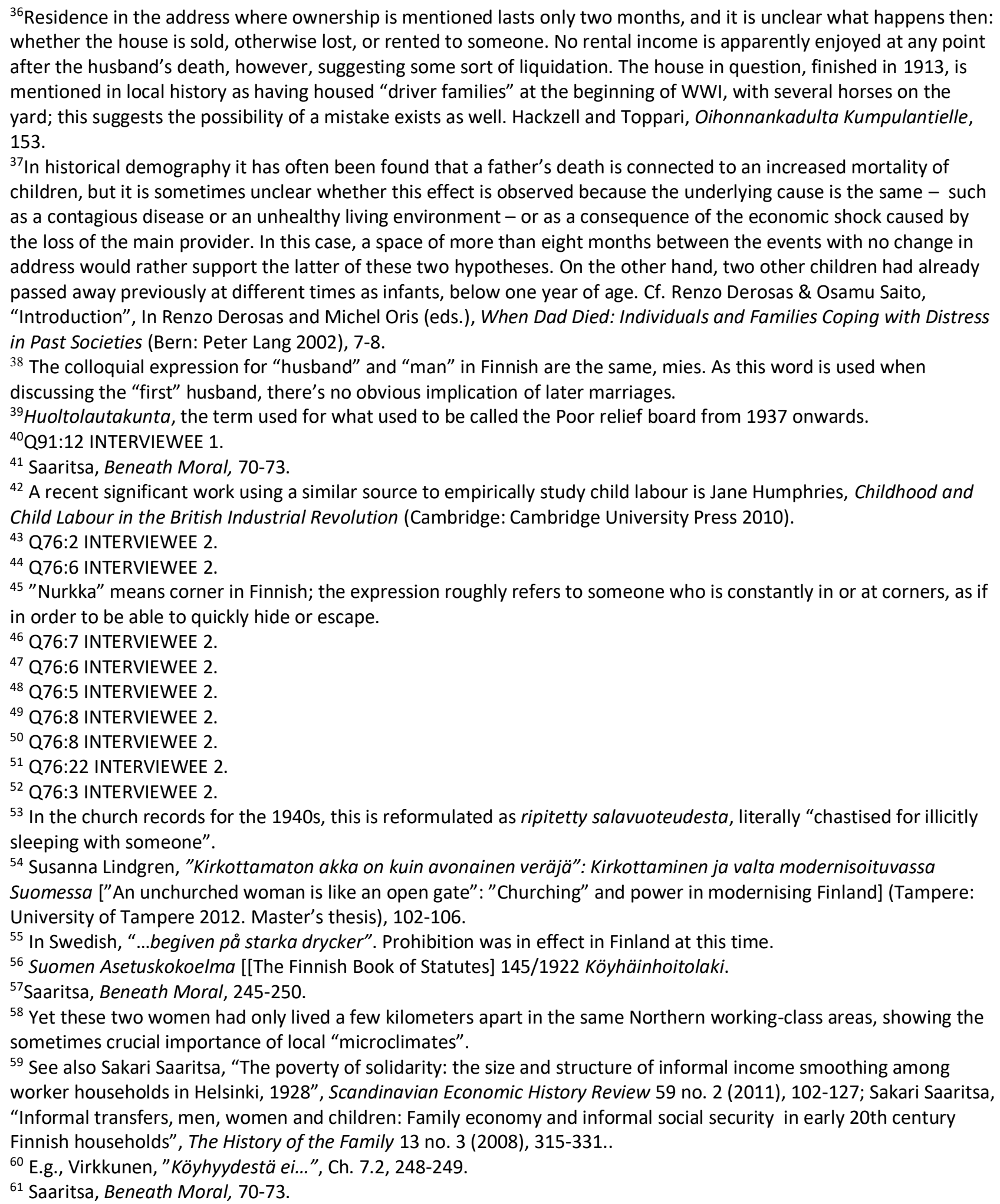

